\title{
Little Bandung as Public Diplomacy of Indonesia
}

\author{
Rifqah Sajidah ${ }^{1}$, Zein Nidaulhaq Firdaus ${ }^{2}$, Stanijuanita Marantika ${ }^{3}$, Izza Firdausi ${ }^{4}$
}

\begin{abstract}
One of ASEAN purpose is accelerating the economic growth in its countries members and the form of manifestation is the ASEAN Economic Community (AEC). Small and Medium-sized Enterprises (SMEs) play a role as one of the contributors to economic growth in Indonesia. SMEs have its own potentials and challenges in facing of the AEC. The effort in developing potential and find solutions to the challenges that faced by SMEs need support from all parties, such as the government, the enterprises, and the parties that related with the issue. In the end of 2015, the government of Bandung City introduced a "Little Bandung" program which is one of the efforts and strategies to support the development progress of SMEs in Bandung City to promote the local products, local culinary, tourism and crafts to abroad countries such as Malaysia, France, and South Korea, and it will also broaden to other countries. The methods that used in this paper were the study literature and interviews to collect data about the growing of the SMEs number in Bandung. The program also aims to prepare the Bandung City in facing the ASEAN Economic Community (AEC). This research finds out how the "Little Bandung" program gives impact for the local government and also the impact to the SMEs growth in Bandung City. This paper explains how "Little Bandung" could become a tool in public diplomacy to introduce Indonesian cultures, tourism, and other unique features especially in Bandung City that ultimately expected to give some positive impacts on the economy of Indonesia. The preliminary result of this research are to introduce Bandung City to the international world and also to improve the competitiveness of the SMEs actors.
\end{abstract}

Keywords - AEC, little bandung, public diplomacy, SMEs.

\section{INTRODUCTION}

The location of Indonesia is highly strategic because it is located in the Southeast Asian region that provides a lot of impact in terms of regional cooperation, economic, political and security, social and cultural. Association of Southeast Asian Nations (ASEAN) usually referred to an organization which aims at realizing regional cooperation in particular countries in Southeast Asia region. Based on the declaration of ASEAN, then made purpose of this association, one of which is to accelerate the economic growth in order to reach the peaceful and prosperous people in Southeast Asia. To realizing the ideals of the establishment of ASEAN, there is an initiation of regional economic cooperation called ASEAN Economic Community (AEC). AEC will serve as the region with equitable economic development, with one of them is to prioritize the development of Small and Medium Enterprises

Rifqah Sajidah $^{1}$, Zein Nidaulhaq Firdaus ${ }^{2}$, Stanijuanita Marantika ${ }^{3}$, Izza

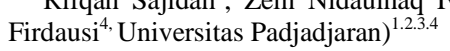

(SMEs).

Small and Medium Enterprises (SMEs) is very important because it could be the key to create jobs and increasing the economic growth in national and regional level. In addition, SMEs have many advantages include it durability in facing the crisis. [1] Recorded in history of Indonesia, SMEs have proved to be able to withstand economic crisis and be the savior of the economy in the 1997 financial crisis and the global crisis of 2008. This is due to the flexibility of SMEs to adapt their production process, and be able to develop their own capital and have no dependency with loans from abroad. The competitiveness and dynamism of SMEs will be improved by facilitating their access to the latest information, market conditions, the development of human resources in terms of capacity building, finance, and technology. SMEs development in the countries of Southeast Asia have strengthened again and poured into a Strategic Action Plan for SME Development (SAPSMED) from 2016 to 2025 with the vision 'Globally Competitive and Innovative SME' to built the innovative SMEs and competitive in global scale. [2].

\section{LITTLE BANDUNG}

In Indonesia, Bandung City was awarded as the best city in the development of SMEs in Indonesia on 2016 and could be a role-model for other districts in Indonesia. Bandung was awarded because of its ability to create good economic climate as well as local products Bandung managed to penetrate international markets and this also the good thing that owned by the Bandung City. [3]

Bandung also known as Paris van Java which has a very great potential in the creative industries. In 2015, the United Nations Educational, Scientific and Cultural Organization (UNESCO) announced Bandung as one of the creative city in UNESCO Creative Cities Network [4][5], it shows that Bandung has been recognized in the international scale which related with the creative industries. With a very large potential of the creative industries, Bandung is the center of creativity in Indonesia such as crafts, textiles, clothing, art and culture. Some other creative industry sector, among others, music, design, architecture, culinary, and many tourist destinations. The growth of SMEs is further increased because the number of tourists who visits during holiday or weekends.

Bandung Creative City Forum (BCCF) or is a crosscommunity forums and creative organization declared and established by a variety of creative community in Bandung on December 21, 2008. As an official organization, BCCF has been transformed into an independent organization which has 
a goal to be able to provide benefits for society in general and particularly to the creative community in the city of Bandung. In their activities, BCCF use creativity-based education approach, planning and improvement of the city infrastructure in order to support creating the development of creative economy and creative entrepreneurs either individual or community. At the end, this forum participated to initiate the development of branding strategies and building the broadest network as a collective effort in order to make the city of Bandung as a creative city that ready to collaborate while competing in global scale. [6]

Contributions that given by the government in the development of SMEs is a real program and more effective compared to the other districts. In terms of capital, Bandung has a credit programs without collateral (kredit melati), freeing the business license for small businesses, in internanational scale, there is a program called "Little Bandung" as a forum for Bandung local products to market their products to the international markets. Bandung could run the program independently without having to rely on the central government. Little Bandung program have shown Indonesia to be able to compete in the ASEAN Economic Community with other countries.

Little Bandung was first introduced to the international scale by the Mayor of Bandung, Ridwan Kamil in France on 2015. The concept of Little Bandung is generally to introducing the culture of Indonesia into the world and particularly through SMEs that will sell typical Indonesian cultural products, culinary destinations, local crafts, fashion, and unique items and distinctive works of youth creativity in Bandung. [7]

Afterwards, Little Bandung opened in Seoul, South Korea on October 2015 while Bandung and Seoul implemented cooperations between two cities such as urban economy, urban planning, urban transportation, e-government, cultire and capacity building [8]. In October 6, Little Bandung introduced in Petaling Jaya, Malaysia. Mayor of Bandung City, Ridwan Kamil said that the opening of Little Bandung in Malaysia is a real one small step to reach the goal that can give a major impact to strengthened cooperation between Indonesia and Malaysia [9]. It also aims to strengthen the economic, trade, social and cultural between two countries. Little Bandung also a manifestation of the role of both countries in order to building the people-to-people relations. It is also a form of cooperation between the sister city, Bandung City and Petaling Jaya City to expected to create a mutually beneficial relationship for the people of the two cities and two countries.

\section{PUBlic DiPLOMACY}

The traditional diplomacy is considered less effective in running it so that it appears a new form of diplomacy in which the kind of this diplomacy, state is no longer the main actors in international issues to discuss either under the government or not. Even in the issues addressed in the public diplomacy not only revolved about the security but also like to discuss about the social and economic welfare [10].

Over the time, diplomacy that run by the government becomes less effective. This is due to the dynamic rapid development of a in international relations. Furthermore, non- state actors also favor the occurrence of this case, to the community can take part in the diplomatic process. With the increasing role of non-State actors of society as well as other causes envoy of the State becomes ineffective in diplomacy [11].So it takes public diplomacy as the answer to all these problems.

The definition of public diplomacy itself according Cull, that an experiment of international actors in managing international environment through his relationship with the community [12]. Public diplomacy emphasizes inter-cultural communication for sustainable public diplomacy that very close with the community in looking for the changes in international political problems.

The relationships that established through public diplomacy then expected to create a good environment for communities among countries to cooperate with each other and promote the growth of transactions between them. Leonard considers that there are three goals that can be achieved with the existence of public diplomacy, that is [13]:

1. Increase the sense of kinship with other countries, by making a good image of the country.

2. Increase public recognition to a particular country, such as having a positive perception.

3. strengthen the relationships with communities in one country, for example by means of education into scientific cooperation, to convince the people in the country to come to the tourism destination, become consumers of local products, give knowledge about values that upheld by the actor.

4. Influencing people in other countries to invest and became a partner in political relations.

Little Bandung is one of the implementation of the concept of public diplomacy that provides the knowledge and values of Indonesia to other countries. It could give many impacts on economic growth in Indonesia, especially in Bandung. From Little Bandung, it can introduce that Indonesia is a country with many natural resources, arts and culture, attractive tourist destination to visit. Because in public diplomacy also emphasizes inter-cultural communication that also supports to achieve the sustainable development goals.

\section{ACKNOWLEDGEMENTS}

Little Bandung program that still exist is expected to provide a positive and significant impact on sustainable development in Indonesia. It also expected to be an example and can be implemented by other districts in Indonesia and even in the international scale. Because in the era of free market, many things that will be popping up both opportunities and challenges. With the opportunities that exist, positive things can be developed much better for the future. Also the challenges that exist, have pushed to find a solution to solve it. Increasing the creativeness in a society nowadays also become an important things because it will be able to enhance the competitiveness the society in competing to the national and international scale. 


\section{REFERENCE}

[1] Wignaraja, G. "Go back to basics to help ASEAN SMEs benefit from AEC". Retrieved from, https://blogs.adb.org/blog/go-back-basics-helpasean-smes-benefit-aec, on January 23, 2017.

[2] ASEAN SMEs Working Group. (2014). Beyond AEC 2015: Policy Recommendations for ASEAN SME Competitiveness. Rerieved from, https://www.usasean.org/system/files/downloads/sme_report_beyondaec 2015.pdf

[3] Ramdhani, D. "Bandung Diberi Penghargaan Kota Terbaik dalam Pengembangan UKM". Retrieved from, http://regional.kompas.com/read/2016/11/30/13532821/bandung.diberi.p enghargaan.kota.terbaik.dalam.pengembangan.ukm, on January 23, 2017

[4] Gibbons, Z. "UNESCO umumkan Bandung masuk dalam jaringan kota kreatif". $\quad$ Retrieved from, http://www.antaranews.com/berita/534718/unesco-umumkan-bandungmasuk-dalam-jaringan-kota-kreatif, on January 23, 2017.

[5] UNESCO Headquarters. "47 Cities Join the UNESCO Creatice Cities Networks". Retrieved from, http://en.unesco.org/creativecities/events/47-cities-join-unesco-creative-cities-network, on January 23, 2017.

[6] Bandung Creative City Forum. "About BCCF". Retrieved from, https://bandungcreativecityforum.wordpress.com/about/, on January 23, 2017.

[7] Lestari, D and Asmara, C. "Ridwan Kamil Sombongkan Little Bandung Sudah Masuk ke Paris". Retrieved from, http://bisnis.news.viva.co.id/news/read/772853-ridwan-nbsp-kamilsombongkan-little-bandung-sudah-masuk-ke-paris, on January 23, 2017

[8] Pemerintah Provinsi Jawa Barat. "Bandung Siap Rambah Seoul Melalui Budaya”. Retrieved from, http://www.jabarprov.go.id/index.php/news/12481/2015/05/27/Bandung -Siap-Rambah-Seoul-Melalui-Budaya, on January 23, 2017.

[9] Ministry of Trade Republic of Indonesia. "Little Bandung Hadir di Malaysia". Retrieved from, http://www.kemendag.go.id/files/pdf/2016/10/06/little-bandung-hadirdi-malaysia-id0-1475739746.pdf, on January 23, 2017.

[10] White Paper On Tourisme in Japan. (2005). Tokyo Ministry Land, Infrasturcture and Tourism Japan

[11] Dhitra, A. (2013). Misi Kebudayaan Sebagai Alat Diplomasi.

[12] Cull, N. J. (2009). Public diplomacy : Lesson from the Past. Los Angels Figueroa Press.

[13] Leonard, M. (2002). Public Diplomacy. The Foreign Policy Centre. London 